
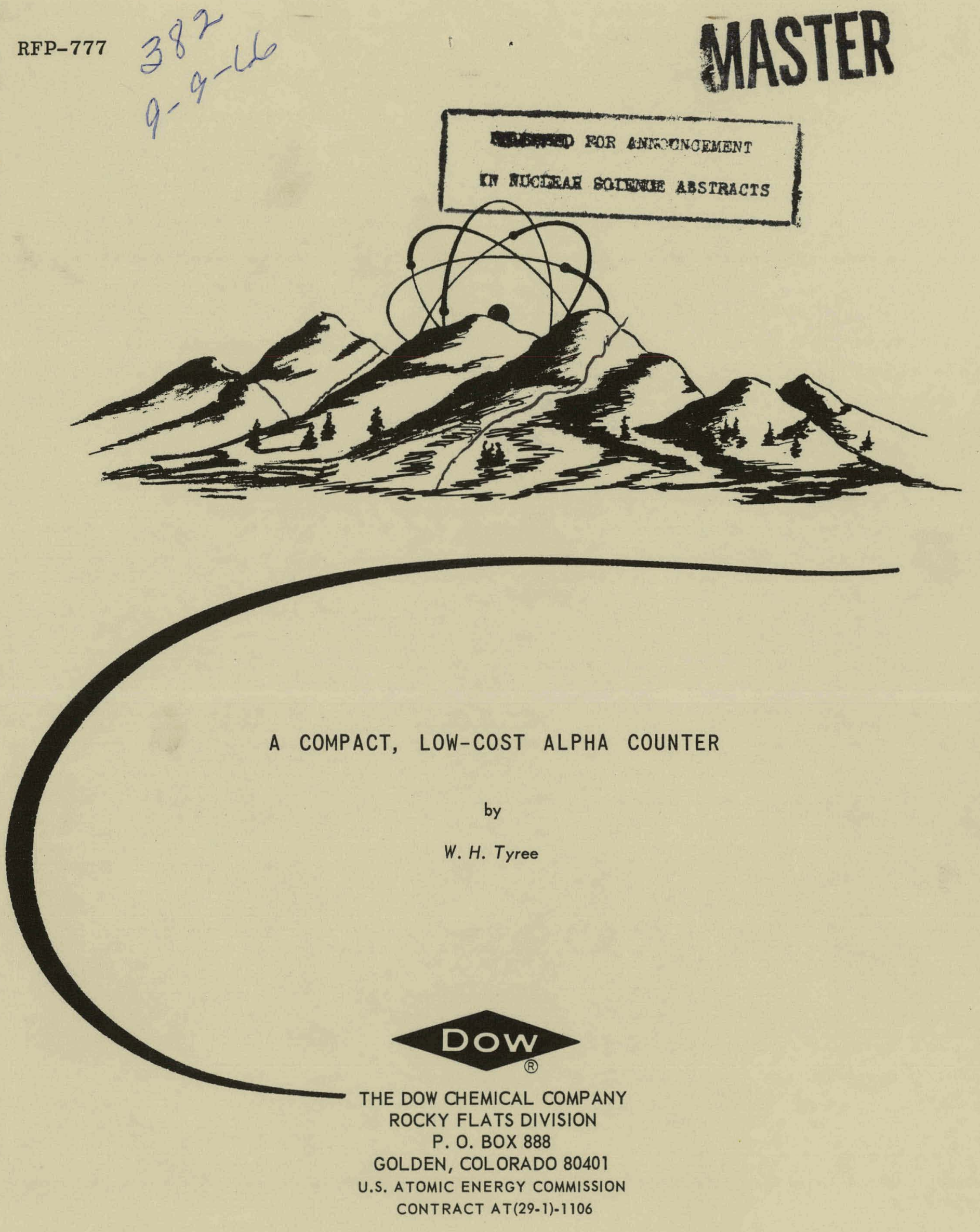


\section{DISCLAIMER}

This report was prepared as an account of work sponsored by an agency of the United States Government. Neither the United States Government nor any agency Thereof, nor any of their employees, makes any warranty, express or implied, or assumes any legal liability or responsibility for the accuracy, completeness, or usefulness of any information, apparatus, product, or process disclosed, or represents that its use would not infringe privately owned rights. Reference herein to any specific commercial product, process, or service by trade name, trademark, manufacturer, or otherwise does not necessarily constitute or imply its endorsement, recommendation, or favoring by the United States Government or any agency thereof. The views and opinions of authors expressed herein do not necessarily state or reflect those of the United States Government or any agency thereof. 


\section{DISCLAIMER}

Portions of this document may be illegible in electronic image products. Images are produced from the best available original document. 


\section{LEGAL NOTICE}

This report was prepared as an account of Government sponsored work. Neither the United States, nor the Commission, nor any person acting on behalf of the Commission:

A. Makes any warranty or representation, expressed or implied, with respect to the accuracy, completeness, or usefulness of the information contained in this report, or that the use of any information, apparatus, method, or process disclosed in this report may not infringe privately owned rights; or

B. Assumes any liabilities with respect to the use of, or for damages resulting from the use of any information, apparatus, method, or process disclosed in this report.

As used in the above, "person acting on behalf of the Commission" includes any employee or contractor of the Commission, or employee of such contractor, to the extent that such employee or contractor of the Commission, or employee of such contractor prepares, disseminates, or provides access to, any information pursuant to his employment or contract with the Commission, or his employment with such contractor.

Printed in USA. Price $\$ 1$. Available from the Clearinghouse for Federal Scientific and Technical Information, National Bureau of Standards,

U. S. Department of Commerce, Springfield, Virginia 
RFP-777

UC-37 INSTRUMENTS

TID-4500

\section{CFSTI PRICES}

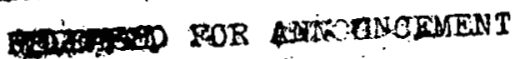

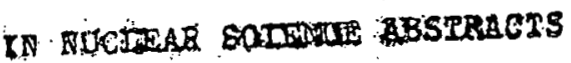

H. C. $\$ 1.00 ; \mathrm{MR}$

\title{
A COMPACT, LOW-COST ALPHA COUNTER
}

by

W. H. Tyree

\begin{abstract}
LEGAL NOTICE
Thio rupunt

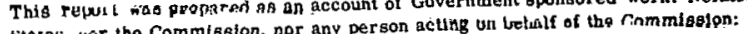

States, wor the Commission, nor any person aclion, expressed or implifed, with respect to the accu-

A. Makes any warranty or representation, expressed. racy, cimplcteness, or usefulness of the information contained in thro report, or that inf inge of any. information, spparatus

privately owned rights: or

B. Assumes any llabilites with respect to the use of, or for damages result

use of any information, apparatus, meltiul, or process of the Commission" includes any con.

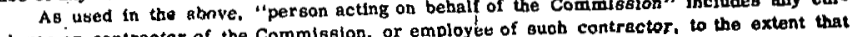
ployee or contractor of the Commlsston, or emplof of such employee or contractor of the Commission, of employee to tis employment or contract disseminates, or provides access to, any intor math pur.

with the Commisston, or mis employment with such contractor.

Whe the com
\end{abstract}

THE DOW CHEMICAL COMPANY

ROCKY FLATS DIVISION

P. O. BOX 888

GOLDEN, COLORADO 80401

U.S. ATOMIC ENERGY COMMISSION CONTRACT AT(29-1)-1106 


\begin{abstract}
An alpha counter with meter readout is described. The cost of the counter including an air proportional detector and rechargeable batteries is less than $\$ 65.00$.
\end{abstract}




\section{CONTENTS}

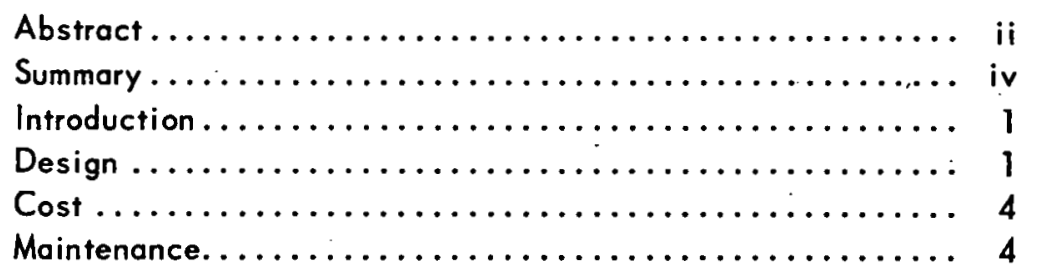




\section{SUMMARY}

An inexpensive counter featuring low-current drain has been bullt. Thè counter includes a high voltage supply, large meter readout, plug-in transistors, and rechargeable batteries. These. units are in use at the Rocky Flats Division of The Dow Chemical. Company. 


\section{INTRODUCTION}

The control of radioactive material in an industrial process area is enhanced by providing readily accessible radiation counters. This makes it possible for operating personnel to monitor themselves and their immediate work area. We use alpha counting instruments in plutonium process areas to indicate surface contamination. A health physics monitor is called to determine the extent of contamination only in the event of a positive indication.

Previous development of alpha counters at Rocky Flats for process areas produced a small, low-cost alpha counter, (I) the Alpha Flasher, but it required daily attention. The new alpha-meter counter is capable of continuous 2-week operation

\section{DESIGN}

A large meter is used for readout instead of a flashing light or an aural output. The size of the meter is as large as the enclosure will permit; this allows the indicator to be observed easily.

The meter used in the alpha-meter provides a large indicator without the volume occupied by conventional D'Arsonval movements. . This allows the mounting of two printed circuit boards immediately behind the meter. The volume of the counter is 31.5 inches ${ }^{3}$.

The elcctronic circuits in the counter have been mounted on two boards. The Amplifier-Trigger and Power Supply boards are mounted in separate compartments to reduce pickup by the amplifier of the power supply ripple voltage.
The Amplifier-Trigger board includes two variable controls, an amplifier gain control and a rheostat to control the maximum deflection of the meter. All transistors are mounted in sockets to facilitate servicing.

The circuit is capable of operation over a temperature range of $60^{\circ} \mathrm{F}$ to $100^{\circ} \mathrm{F}$. This is adequate with a temperature controlled environment. The amplifiers are biased with base current injection for low battery drain. The gain of the amplifier is about 150 at full gain. The gain control is used to control the pulse amplitude triggering the monostable multivibrator. The output pulse width from the multivibrator is 35 milliseconds. The width of the pulse determines the full-scale deflection of the meter. The meter scale is divided into two sections, the lower third is green with the remaining portion red.

The alpha-meter is adjusted to produce full-scale deflection with a $6000-\mathrm{d} / \mathrm{m}$ source held at the window of the air proportional detector. The Amplifier-Trigger circuit requires 1.2 milliampere at 2.5 volts.

The high voltage power supplies we have previously used in small alpha counters hove utilized either inefficient audio transformers or expensive but efficient toroid transformers. The transformer used in the alpha-meter power supply is a commercially available blocking oscillator transformer operating at about 30 percent of its rated output voltage. The high voltage is developed by a single transistor blocking oscillator with a diode-capacitor quintupler network in the output of the transformer.

(1) Tyree, W. H., and Johnson, V. P., An Alpho Counter for Glove Box Operations, The Dow Chemical Company, Rocky Flats Division, August 15, 1963, RFP-348.

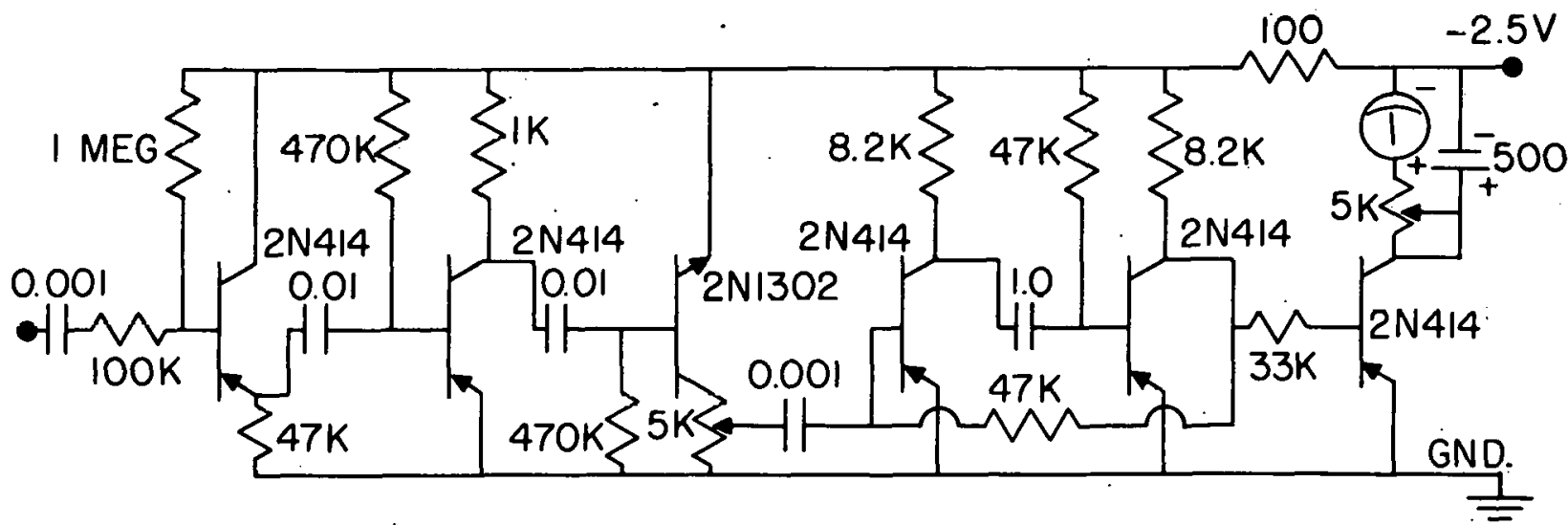

Figure 1. AMPLIFIER-TRIGGER 


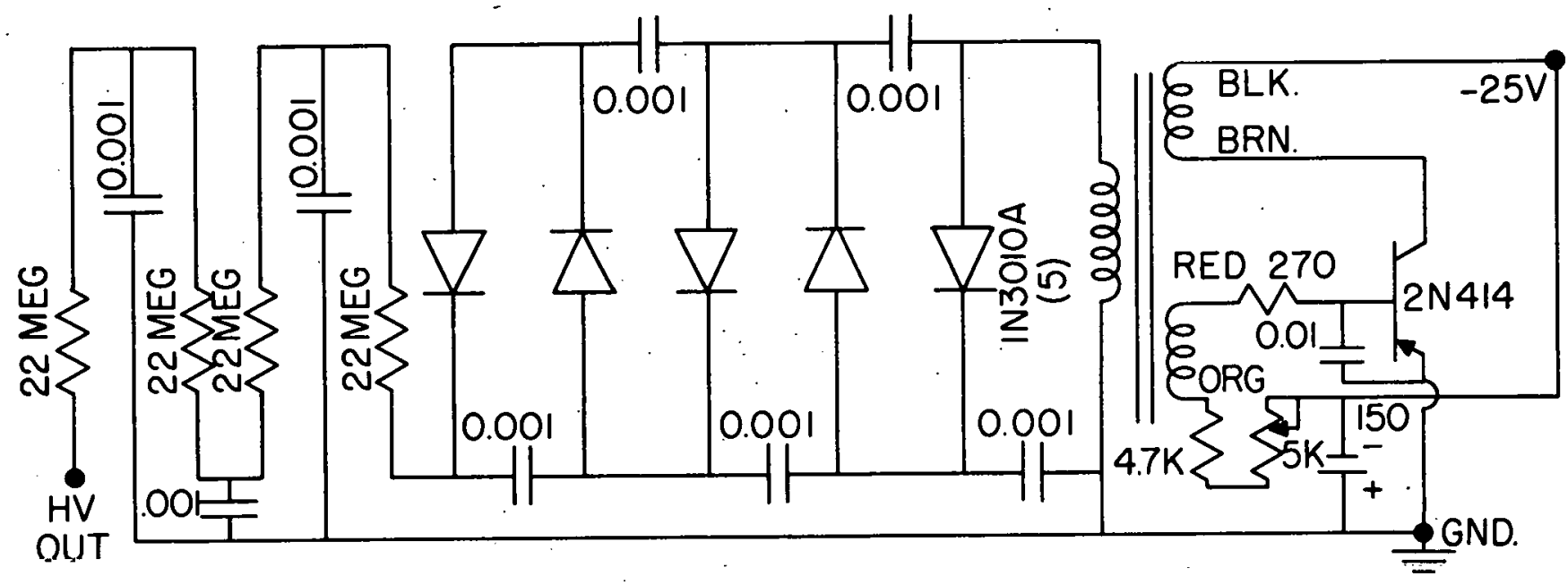

Figure 2. POWER SUPPLY

The transformer output voltage is raised to about 1900 volts through the network for air proportional detector operation at our 6000-foot elevation. The circuit will operate with any type of high-beta, medium- to highfrequency, PNP germanium transistor. The oscillator starts easily and produces the rated output voltage within 5 seconds.
Since the high voltage supply provides detector potential at near zero power, the current required from the batteries is only that needed to compensate for internal losses. The current drain of the power supply is a function of the peak inverse voltage rating of the silicon diodes used in the diode-capacitor network. The graph shows the effect of the peak inverse voltage.

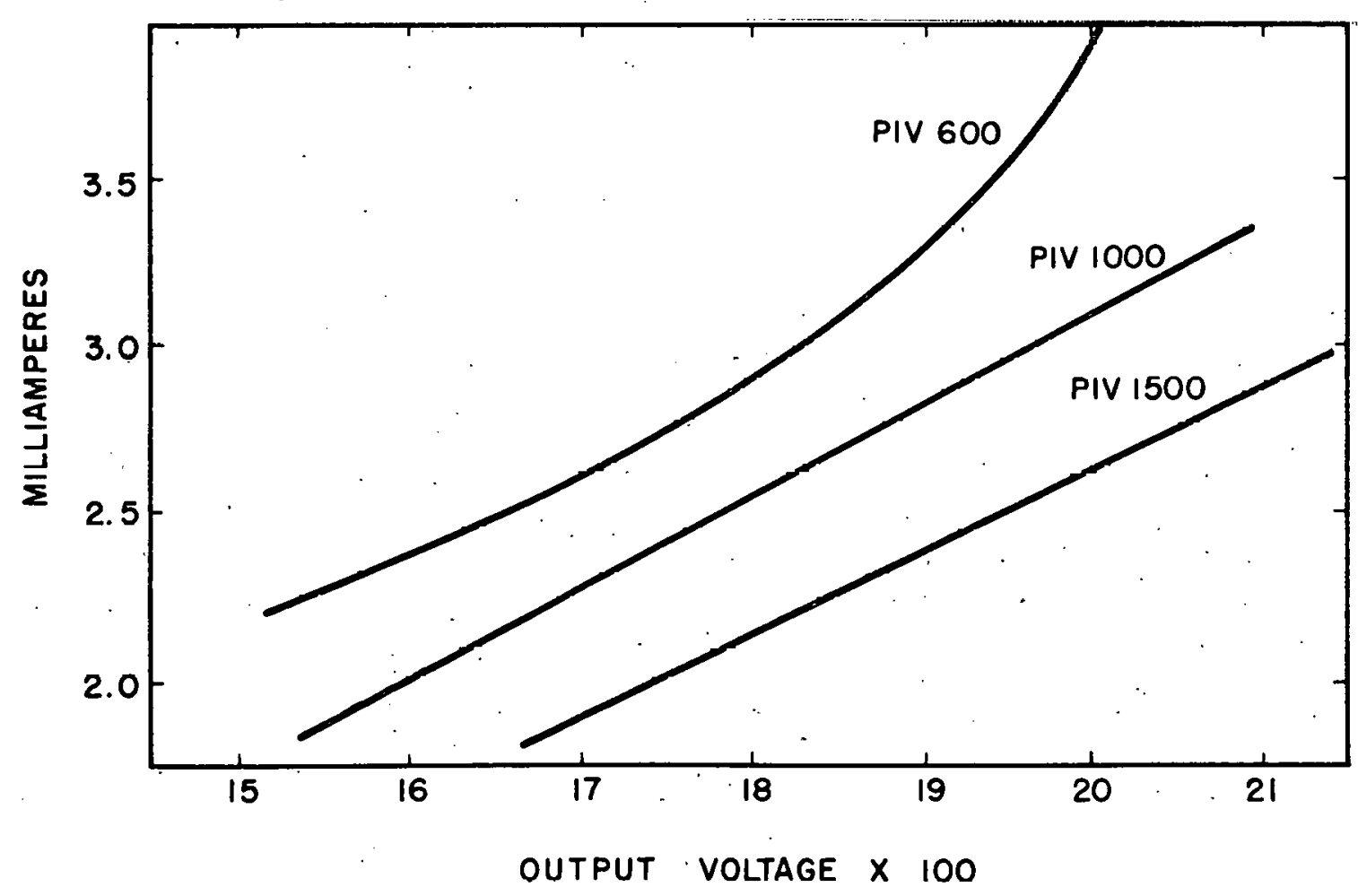


The average total current drain of the Amplifier-Trigger circuit and the Power Supply circuit is 4.6 milliamperes. The exact current drain of any particular counter will depend upon the condition and type of diodes used in the power supply.

\section{COST}

The counters in quantity cost $\$ 47.81$ without the detector or batteries. The air proportional detector cost $\$ 8.00$ in quantity. The two batteries cost \$7.42. The total cost for the alpha-meter is $\$ 63.23$.

\section{MAINTENANCE}

The alpha-meter includes features that facilitate rapid service and repair.

The counter includes printed circuit boards with socketmounted transistors, a plug-in battery pack, and a removable air proportional detector. The nickel-cadmium rechargeable batteries produce 2 weeks of continuous counter operation. 
RFP-777 